\title{
Asynchronous replication of biallelically expressed loci: A new phenomenon in Turner syndrome
}

\author{
Orit Reish, $M D^{1,2,3}$, Ron Gal, $M D^{1,3,4}$, Elena Gaber, $P h D^{4}$, Carron Sher, $M D^{1}$, Tzvy Bistritzer, $M D^{2,3}$, and
} Aliza Amiel, $\mathrm{PhD}^{2,4}$

\begin{abstract}
Purpose: Transcriptional activity of genes is related to their replication timing; alleles showing the common biallelic mode of expression replicate synchronously, whereas those with a monoallelic mode of expression replicate asynchronously. Here the level of synchronization in replication timing of alleles was determined in subjects with Turner syndrome. Methods: Fluorescence in situ hybridization was used for three loci not linked to X chromosome, in lymphocytes derived from 12 controls, 3 individuals with Turner, and 4 with mosaic Turner syndrome. Results: In cells derived from controls, each pair of alleles replicated synchronously; yet these same alleles replicated asynchronously in cells monosomic for $\mathrm{X}$ chromosome derived from Turner and mosaic Turner patients. When the level of $45, X$ was low in the mosaic samples, the replication pattern of the $46, X X$ cells was normal. However, in samples with a high level of mosaicism, a significantly increased asynchronous replication was detected in the 46,XX cells. Conclusion: An altered temporal replication control in Turner syndrome affecting the aneuploid and euploid cells is shown. This alteration may potentially be involved in the determination of the syndrome. Genet Med
\end{abstract} 2002:4(6):439-443.

Key Words: Turner syndrome, mosaic, replication timing, asynchrony, fluorescence in situ hybridization

Replication patterns of known protein-encoding DNA sequences reveal a correlation between the specific time interval during the S-phase (of the cell cycle) at which a given DNA sequence in a given tissue is being replicated and its transcriptional status: expressed loci usually replicate early, while unexpressed ones replicate late. Hence, in many cell types, most housekeeping genes replicate early, whereas most tissue-specific genes demonstrate a differentiation-dependent pattern of replication, undergoing early replication in cells where they are expressed and late in cells where they are not expressed. ${ }^{1-3}$

Recent fluorescence in situ hybridization (FISH) methods enable investigators to determine replication timing of allelic DNA sequences in unsynchronized cell populations. ${ }^{4,5}$ Accordingly, an unreplicated DNA sequence at interphase is manifested by a single fluorescent signal (singlet; S) while a replicated sequence gives rise to a double signal (doublet; D). Thus, in a population of replicating cells, a high frequency of nuclei with two similar hybridization signals, either two singlets (SS) or two doublets (DD), would indicate a pair of allelic loci that replicates synchronously. Conversely, allelic loci that replicate asynchronously are revealed by a high frequency of

\footnotetext{
From the ${ }^{I}$ Genetic Institute, Assaf Harofeh Medical Center, Zerifin, Israel; ${ }^{2}$ Sackler School of Medicine, Tel Aviv University, Tel Aviv, Israel; ${ }^{3}$ Department of Pediatrics, Assaf Harofeh Medical Center, Zerifin, Israel; and ${ }^{4}$ Genetic Institute Meir Medical Center, Kfar Saba, Israel. This work fulfills in part the research requirements for the pediatric residency of R.G. Orit Reish, MD, Genetic Institute, Assaf Harofeh Medical Center, Zerifin, 70300 Israel. Received: April 16, 2002.

Accepted: July 31, 2002.
}

DOI: 10.1097/01.GIM.0000035540.15027.AE nuclei containing two different hybridization signals-a singlet and doublet (SD).6,7

Several studies, using the FISH method to estimate the replication timing of one allele relative to its counterpart within the same cell, have clearly shown that concomitantly expressed alleles replicate synchronously. ${ }^{6-8}$ In contrast, alleles subjected to an allele-specific mode of expression, due to imprinting, ${ }^{7,9-11} \mathrm{X}$ chromosome inactivation, ${ }^{8}$ or some other mechanism leading to monoallelic expression, ${ }^{12-14}$ replicate asynchronously. Thus the tight association between replication timing of a gene and its transcriptional status enabled FISH methodology to be used as a reliable tool for detection of gene activity in different tissues. ${ }^{5,6,14}$

New evidence based on replication studies suggests that the phenotypic abnormalities associated with an extra chromosome are caused not only by overexpression of genes present in three doses, but also by the modification of expression of other genes present in two doses. Moreover, the changes in the expression of genes present in two doses were not dependent on the source of the extra chromosome. ${ }^{15,16}$ In these studies it was shown that the loss of replication synchrony of three biallelically expressed genes (RB-1, HER2, and AML1) was more significant in amniocytes derived from subjects with trisomies 18 and 13 than from those with trisomy 21. On the other hand, cells derived from subjects carrying a sex chromosome trisomy, 47,XXX and 47,XXY, showed a normal pattern of allelic replication. Thus a correlation between the degree of replication asynchrony reflecting modification in allelic expression and the severity of the phenotypic abnormality was suggested. ${ }^{16}$ 
Turner syndrome is a common disorder affecting approximately 1 per 2,500 live-born females. Among these, about 50\% have a $45, \mathrm{X}$ chromosomal constitution and the remainder have a second cell line containing two sex chromosomes. ${ }^{17}$ Cytogenetic studies of spontaneous abortions have shown that more than $99 \%$ of conspectuses with a 45 , X chromosome constitution abort spontaneously or are stillborn and only $0.3 \%$ survive to term. The reason for this is not obvious. ${ }^{18}$

In the present study we analyzed the replication pattern of allelic counterpart of $p 53, R B-1$, and $c-m y c$ genes in subjects with $45, \mathrm{X}$ (Turner) and mosaic 45,X/46,XX (mosaic Turner) chromosomal constitutions. The aim of this study was to determine whether genes that are not located on the X chromosome are subjected to modification in their replication pattern when present in cells carrying monosomy for the X chromosome, in comparison with cells with a normal chromosomal constitution. This study may shed light on the mechanisms leading to the Turner syndrome phenotype.

\section{MATERIALS AND METHODS}

\section{Samples}

Phytohemagglutinin (PHA)-stimulated lymphocyte cultures were evaluated from 7 patients with Turner or mosaic Turner syndrome (study group; samples 13-19) and from 12 healthy ageand sex-matched control females with normal 46,XX constitution (samples 1-12) (Table 1). To designate the karyotype, at least 50 and 15 metaphase cells from each of the study and control samples, respectively, were examined, using $\mathrm{G}$ banding. The study group included three patients with $45, \mathrm{X}$ karyotype, detected in all evaluated cells (samples 13-15, in those samples the presence of a $\mathrm{Y}$ chromosome was excluded), and four patients with mosaic Turner with variable range of $\mathrm{X}$ chromosome monosomy (samples 16-19) (Table 2). Two mosaic Turner patients, samples 16 and 17 , revealed a low mosaicism of 45 ,X cells ( $8 \%$ and $18 \%$, respectively), while the other two, samples 18 and 19, revealed a higher frequency of $45, \mathrm{X}$ mosaicism ( $76 \%$ and $80 \%$, respectively). To determine the level of $45, \mathrm{X}$ mosaicism, at least 416 interphase cells were scored from each sample, using FISH with an X-chromosome-specific probe (Table 2).

Informed consent was obtained from the patients or their parents. The project was approved by the institutional review board.

\section{Cytogenetics}

Peripheral blood samples from each tested subject were incubated for short-term culture in an F10-supplemented medium in a $37^{\circ} \mathrm{C}$ moist chamber for 72 hours. The supplemented medium contained $20 \%$ fetal calf serum, PHA, and $1 \%$ antibiotics. After incubation, colchicine (final concentration $0.1 \mu \mathrm{g} /$ $\mathrm{mL}$ ) was added to the cultures for 1 hour, followed by hypotonic treatment $(0.075 \mathrm{~mol} / \mathrm{L} \mathrm{KCl})$ at $37^{\circ} \mathrm{C}$ for 15 minutes and

\section{Table 1}

Frequency (\%) of SD cells for the designated locus in samples of normal control $(46, \mathrm{XX})$ females (samples $1-12)$ and Turner syndrome (45,X) patients (samples 13-15)

\begin{tabular}{|c|c|c|c|c|c|}
\hline & $\begin{array}{l}\text { Individual } \\
\text { designation }\end{array}$ & $p 53$ & $R B-1$ & $c-m y c$ & $\begin{array}{l}\text { Mean } \pm \text { standard } \\
\text { deviation }\end{array}$ \\
\hline \multirow[t]{12}{*}{ Control $(46, \mathrm{XX})$ samples $1-12$} & 1 & - & - & 6 & - \\
\hline & 2 & - & - & 5 & - \\
\hline & 3 & - & - & 7 & - \\
\hline & 4 & - & - & 8 & - \\
\hline & 5 & - & - & 11 & - \\
\hline & 6 & 12 & 11 & - & - \\
\hline & 7 & 12 & 12 & - & - \\
\hline & 8 & 13 & 12 & - & - \\
\hline & 9 & 10 & 11 & - & - \\
\hline & 10 & 11 & 10 & - & - \\
\hline & 11 & 8 & 13 & - & - \\
\hline & 12 & 10 & 10 & - & - \\
\hline Mean \pm standard deviation & Samples 1-12 & $11 \pm 2(700)$ & $11 \pm 1(700)$ & $7 \pm 2(500)$ & $10 \pm 2(1900)$ \\
\hline \multirow[t]{3}{*}{ Turner $(45, \mathrm{X})$ samples $13-15$} & 13 & $36(196)$ & 27 (189) & $31(191)$ & $31 \pm 5(576)$ \\
\hline & 14 & 35 (197) & $34(197)$ & $33(207)$ & $34 \pm 1(601)$ \\
\hline & 15 & $38(198)$ & $39(197)$ & $38(198)$ & $38 \pm 1(593)$ \\
\hline Mean \pm standard deviation & Samples $13-15$ & $36 \pm 2(591)$ & $33 \pm 6(583)$ & $34 \pm 4(596)$ & $34 \pm 4(1770)$ \\
\hline
\end{tabular}

One hundred cells were scored from each control female for each locus; the number of cells scored per locus from a Turner patient and the total number of cells scored from each group of samples are presented in parentheses. 
four washes, each with a fresh cold 3:1 methanol:acetic acid solution. The lymphocyte suspensions were stored at $(-4)^{\circ} \mathrm{C}$.

\section{Slide preparation}

Glass slides were precleaned for FISH by incubation in concentrated sulfochromic solutions, rinsed first with distilled water and then twice with absolute ethanol, and then dried with a clean cloth. The stored cell suspensions were washed with a fresh cold 3:1 methanol:acetic acid solution and then dropped onto the precleaned slides and air-dried.

\section{Probes}

Three direct-labeled commercial probes were used for the identification of the tested loci: one for the $p 53$ locus (17p13.1, red, Vysis 32-190008), the second for the RB-1 locus (13q14.3, red, Vysis 32-190029), and the third for the $c$-myclocus (8q24, red, Vysis 32-190006). In addition, we used two chromosome-specific probes: one for the identification of the $\mathrm{X}$ chromosome ( $\alpha$-satellite green, Vysis 32-130029) and the second for the identification of the Y chromosome (satellite III red, Vysis 32-130025).

\section{In situ hybridization}

Fresh slide spreads were denatured for 2 minutes in $70 \%$ formamide $2 \times$ saline sodium citrate buffer (SSC) at $70^{\circ} \mathrm{C}$ and dehydrated in a graded ethanol series. The probe mix was then applied to air-warmed slides ( $30 \mu \mathrm{L}$ mix sealed under a $24 \times 50$ $\mathrm{mm}$ glass coverslip) and hybridized for 18 hours at $37^{\circ} \mathrm{C}$ in a moist chamber. After hybridization, the slides were washed in $50 \%$ formamide $2 \times$ SSC for 20 minutes at $43^{\circ} \mathrm{C}$, rinsed in two changes of $2 \times \mathrm{SSC}$ at $37^{\circ} \mathrm{C}$ for 4 minutes each, and placed in $0.05 \%$ Tween 20 (Sigma, St. Louis, MO). The slides were counterstained in 4,6-deamino-2-phenylindole (DAPI) (Sigma) antifade solution and analyzed for simultaneous viewing of fluorescein isothiocyanate, Texas red, and DAPI. An Applied Imaging system was used for the FISH analysis.

\section{Cytogenetic evaluation}

In each sample the three loci $p 53, R B-1$, and $c-m y c$ were analyzed, using two-color FISH, one red for the tested locus and the second green for X chromosome identification. At least
100 interphase cells from each sample for each tested locus were recorded (Tables 1 and 2). All examined cells had two hybridization signals of the tested locus and were classified into three categories according to the replication status of the locus. Cells with two allelic counterparts at the same replication status were designated either as SS or DD, while those displaying two allelic counterparts differing in their replication status were designated SD. The SS refers to two allelic counterparts, both prior to replication, while DD indicates both counterparts after replication and SD reveals two counterparts, one prior to and the other after replication. ${ }^{4,6}$ The slides were blindly scored by two different and independent readers.

\section{Statistical methods}

The multiple comparisons tests (Duncan's method) were applied to test quantitative parameters between the different study groups. All tests applied were two-tailed, and a $P$ value of $5 \%$ or less was considered statistically significant. The data were analyzed using the SAS software (SAS Institute, Cary, NC).

\section{RESULTS}

The replication pattern of three loci ( $p 53, R B-1$, and $c-m y c$ ), not associated with the X-chromosome, was assessed in PHAstimulated lymphocytes derived from 12 normal controls (samples 1-12; Table 1) and 7 individuals from the study group (samples 13-19; Tables 1 and 2).

The frequency of cells with asynchronous replication of two allelic counterparts (as indicated by the percentage of SD cells) in the control samples $(46, \mathrm{XX})$ and Turner syndrome patients $(45, \mathrm{X})$ differed significantly for all three loci analyzed $(P<$ $0.01)$. The control cells had SD frequency ranging between 7 and $11 \pm 2$, while the SD frequency of Turner cells ranged between 33 and $36 \pm 3$ (Table 1).

The 45,X cells in the four mosaic Turner patients (samples 16-19; Table 2) showed a significantly higher SD frequency in comparison with the control cells $(P<0.01)$, ranging between 29 and $42 \pm 3$, and the SD frequency was not different from that of the 45 , X cells of Turner samples.

The 46, XX cells in these four mosaic Turner patients showed a direct correlation between the SD frequency and the level of $45, \mathrm{X}$

Table 2

Frequency (\%) of SD cells for the designated locus in monosomic $(45, \mathrm{X})$ and disomic $(46, \mathrm{XX})$ cell samples of mosaic Turner syndrome individuals

\begin{tabular}{|c|c|c|c|c|c|c|c|c|c|}
\hline \multicolumn{2}{|c|}{ Individual designation } & \multicolumn{2}{|c|}{$p 53$} & \multicolumn{2}{|c|}{$R B-1$} & \multicolumn{2}{|c|}{$c-m y c$} & \multicolumn{2}{|c|}{ Mean \pm standard deviation } \\
\hline $\begin{array}{l}\text { Sample } \\
\text { no. }\end{array}$ & $\begin{array}{c}\% \text { of } \\
\text { monosomic } \\
\text { cells }\end{array}$ & $45, \mathrm{X}$ & $46, \mathrm{XX}$ & $45, \mathrm{X}$ & $46, \mathrm{XX}$ & $45, \mathrm{X}$ & $46, \mathrm{XX}$ & $45, \mathrm{X}$ & $46, \mathrm{XX}$ \\
\hline 16 & $8(1250)$ & $38(100)$ & $8(181)$ & $43(100)$ & $8(270)$ & $44(100)$ & $9(183)$ & $42 \pm 3(300)$ & $8 \pm 1(634)$ \\
\hline 17 & $18(555)$ & $41(100)$ & $12(178)$ & $39(100)$ & $9(174)$ & $43(100)$ & $10(175)$ & $41 \pm 2(300)$ & $10 \pm 2(527)$ \\
\hline 18 & $76(416)$ & $36(154)$ & $25(100)$ & $33(147)$ & $18(100)$ & $36(146)$ & $24(100)$ & $35 \pm 2(447)$ & $22 \pm 4(300)$ \\
\hline 19 & $80(500)$ & $26(180)$ & $30(100)$ & $32(182)$ & $29(100)$ & $30(179)$ & $27(100)$ & $29 \pm 3(541)$ & $29 \pm 2(300)$ \\
\hline
\end{tabular}

Each individual is designated by its sample number (16-19) and by the percentage of the monosomic cells in its sample. In parentheses is the number of cells examined for each determination; the mean value of the three loci is presented in the last column. 
mosaicism in the same sample. In samples 16 and 17, which had low levels of $45, \mathrm{X}$ mosaicism ( $8 \%$ and $18 \%$, respectively), the SD frequency of the $46, X X$ cells was 8 and $10 \pm 2$, and similar to the $\mathrm{SD}$ frequency of the control cells. However, when $45, \mathrm{X}$ mosaicism levels were as high as $76 \%$ and $80 \%$ (samples 18 and 19, respectively), a significantly higher SD frequency in the $46, \mathrm{XX}$ cells was detected, ranging between 22 and $29 \pm 2$, respectively $(P<0.01)$. Thus, in mosaic samples, not only were monosomic cells affected, but also the euploid cells residing in the same sample demonstrated a significantly increased SD frequency.

No interloci differences (for $p 53, R B-1$, and $c$-myc) could have been demonstrated in the control, Turner, and mosaic Turner cells.

The frequency of SS (late replicating) cells in Turner (lane 4; Fig. 1) and mosaic Turner (lanes 1-3; Fig. 1) was significantly lower in comparison with the control cells (lane 5; Fig. 1), with the three loci analyzed (Fig. 1, a-c) $(P<0.05)$. Turner cells displayed SS frequency of $42-44 \%$, the 45 , X cells of mosaic Turner showed $41 \%$, and the 46 ,XX cells of mosaic Turner demonstrated $45-47 \%$. The control cells revealed a significantly higher SS frequency of $63-73 \%$. It seems that the SD frequency was increased in Turner, 45,X, and 46,XX cells of mosaic Turner proportionally to the overall decrease in the SS frequency in these samples in the three loci analyzed.

\section{DISCUSSION}

Several mechanisms have been suggested to be involved in the determination of the stigmata of Turner syndrome. These include haploinsufficiency of escapees, i.e., genes that escape inactivation, ${ }^{19}$ level of mosaicism, ${ }^{18}$ and parent-of-origin of the $\mathrm{X}$ chromosome. ${ }^{20}$ In this study an abnormal replication timing of autosomal genes in Turner and mosaic Turner cells was demonstrated. This phenomenon suggests an alteration that may potentially be involved in the condition.

We showed that in normally replicating cells, alleles $p 53$, $R B-1$, and $c-m y c$ displayed a pattern of replication usually shown by concomitantly expressed alleles according to the expected Mendelian manner. In contrast, these same loci, when present in cells with a 45,X constitution in either Turner or mosaic Turner samples, displayed an early and late replication pattern, similar to alleles subjected to a process leading to monoallelic expression. Evidently, this phenomenon is not chromosome-specific, since it was observed for the $p 53$ locus located on chromosome 17 , for $R B-1$ locus mapped to chromosome 13, and $c-m y c$ located on chromosome 8. Therefore, chromosome $\mathrm{X}$ monosomy possibly modifies the replication pattern of other autosomal genes present in two doses from a biallelic mode to a monoallelic one.

This study demonstrated that euploid cells $(46, \mathrm{XX})$ residing in the same sample with aneuploid cells $(45, \mathrm{X})$ displayed an abnormally high SD frequency that correlated with the level of aneuploidy in that specific sample. This is suggestive of a potential interaction between the cells with a possible threshold effect dictated by the level of aneuploidy. Our findings of an increased SD frequency are in accordance with previous stud- a

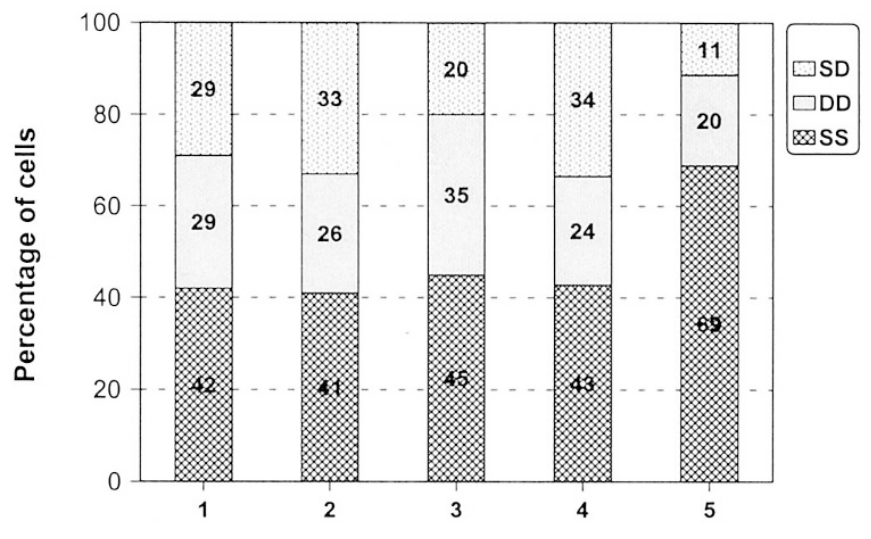

b

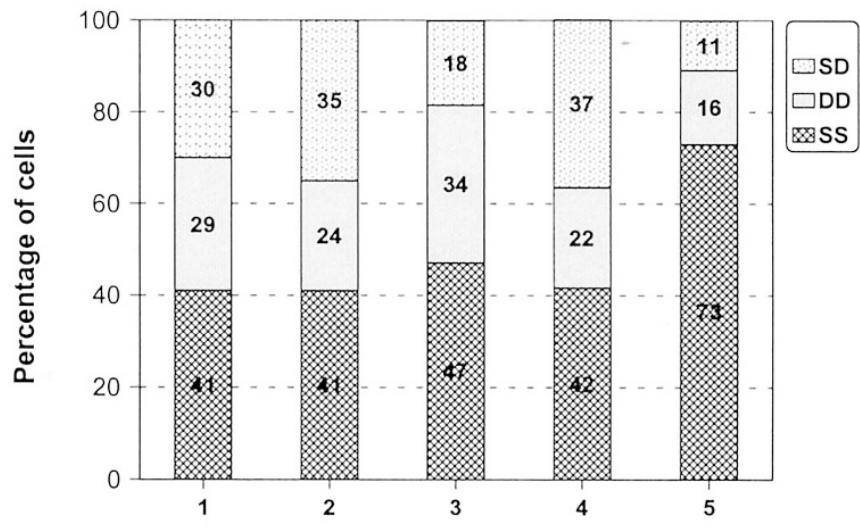

C

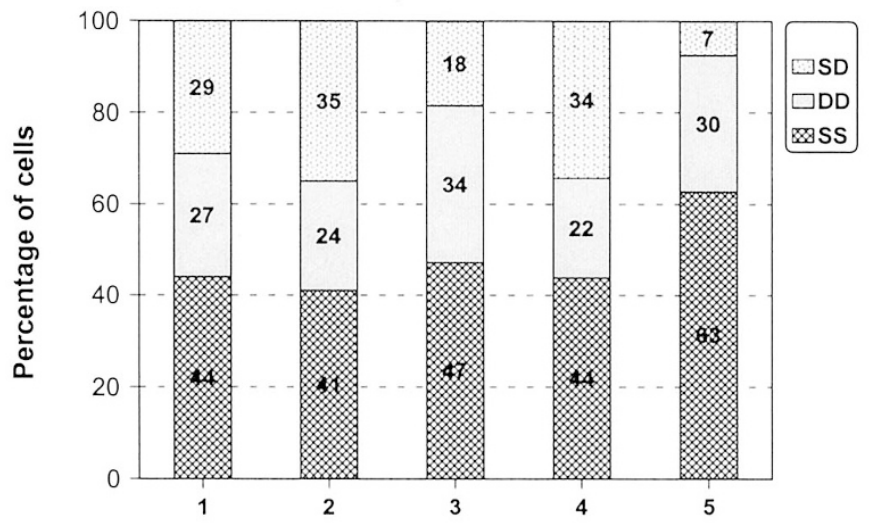

Fig. 1 Frequencies of cells containing two singlets (SS), two doublets (DD), and one singlet and one doublet (SD), following hybridization with different probes: (a) $R B-1$, (b) p53, (c) c-myc. Lanes indicate the different karyotypes: (1) mosaic Turner (45,X/46,XX); (2) 45,X cell type in mosaic Turner; (3) 46,XX cell type in mosaic Turner; (4) Turner $(45, \mathrm{X})$; and (5) control group.

ies demonstrating loss of temporal replication of alleles not associated with the extra chromosome in cells derived from trisomies 21,18 , and $13 .{ }^{16}$

Although extra sex chromosome syndromes such as 47,XXX and 47,XXY did not result in asynchronized allelic mode of repli- 
cation, ${ }^{16}$ in the present study it was demonstrated that X chromosome monosomy has a significantly altered replication control. Previous correlation between the degree of replication asynchrony and the severity of the phenotypic abnormality due to possible altered gene expression was suggested. ${ }^{16}$ We therefore speculate that the discrepancy in replication patterns between monosomy and extra $\mathrm{X}$ chromosomal constitutions may be related to the corresponding severe phenotype of Turner as opposed to Klinefelter and triple X syndromes. This suggested link between altered replication pattern, abnormal gene expression, and degree of phenotypic severity ${ }^{16}$ requires further evaluation.

Scheduled replication is essential for normal growth and development. ${ }^{1-3}$ An abnormally increased asynchronous replication was detected not only in constitutional autosomal trisomies but also in several malignancies. A number of recent studies showed that the biallelically expressed genes ( $p 53, c$ $m y c$, and RB-1, as well as HER2 and AML1), when present in lymphocytes of individuals suffering from various types of leukemia or lymphoma, replicate asynchronously, while these same genes show a synchronous pattern of replication in lymphocytes of normal subjects. ${ }^{21,22}$ Moreover, such a shift from a biallelic to a monoallelic mode of replication was also reported in nonmalignant lymphocytes of renal cell carcinoma patients $^{23}$ and premalignant cells of cervical carcinoma patients. $^{24}$ The increased asynchronous replication of the three loci in the present study, detected in aneuploid and euploid cells derived from Turner and mosaic Turner, seems to be associated with a decrease in the SS frequency of these cells (Fig. 1). This altered SS pattern was previously shown in Down syndrome ${ }^{15}$ and chronic lymphocytic leukemia genomes, ${ }^{25}$ indicating that one allele is early replicating compared to its normal time schedule. It has been previously suggested that this abnormal acceleration in replication pattern might result in activation of a normally silent oncogene. ${ }^{25}$ We therefore speculate that the abnormally increased asynchronous replication demonstrated in Turner and mosaic Turner might be correlated with the altered replication pattern accompanying the cancer phenotype. ${ }^{21,22,24,26}$ If this altered pattern of replication proves in the future to correlate with genomic instability and abnormal gene expression, then the abnormal pattern of replication in Turner may be associated with the various malignancies detected in individuals with the condition that include colon cancer, ${ }^{27,28}$ neuroblastoma, and neural crest-derived tumors. ${ }^{29}$

In conclusion, we demonstrated an altered replication pattern in the aneuploid cells in Turner and mosaic Turner genomes. The euploid cells showed a similar alteration when the aneuploidy level in the sample was increased. This newly detected modified replication pattern may potentially play a role in determination of the Turner condition. Our findings warrant further investigation.

\section{References}

1. Goldman MA, Holmquist GP, Gray MC, Caston LA, Nag A. Replication timing of mammalian genes and middle repetitive sequences. Science 1984;224:686-692.
2. Holmquist GP. Role of replication time in the control of tissue-specific gene expression. Am J Hum Genet 1987;40:151-173.

3. Hatton KS, Dhar VH, Brown EH, Iqbal MA, Stuart S, Didamo VT, Schidkraut CL. Replication program of active and inactive multigene families in mammalian cells. Mol Cell Biol 1988;8:2149-2158.

4. Boggs BA, Chinault AC. Analysis of DNA replication by fluorescence in situ hybridization. Methods 1997;13:259-270.

5. Simon I, Tenzen T, Reubinoff BE, Hillman D, McCarrey JR, Cedar H. Asynchronous replication of imprinted genes is established in the gametes and maintained during development. Nature 1999;401:929-932.

6. Selig S, Okumura K, Ward DC, Cedar H. Delineation of DNA replication time zones by fluorescence in situ hybridization. EMBO J 1992;11:1217-1225.

7. Kitsberg D, Selig S, Brandeis M, Simon I, Keshet I, Driscoll DJ, Nicholls RD, Cedar H. Allele-specific replication timing of imprinted gene regions. Nature 1993;364:459-463.

8. Boggs BA, Chinault AC. Analysis of replication timing properties of human X-chromosomal loci by fluorescence in situ hybridization. Proc Natl Acad Sci U S A 1994; 91:6083-6087.

9. Knoll JHM, Cheng SD, Lalande M. Allele-specificity of DNA replication timing in the Angelman/Prader-Willi syndrome imprinted chromosomal region. Nat Genet 1994;6:41-46.

10. Gunaratne PH, Nakao M, Ledbetter DH, Sutcliffe JS, Chinault AC. Tissue-specific and allele-specific replication timing control in the imprinted human Prader-Willi syndrome region. Genes Dev 1995;9:808-820.

11. White LM, Rogan PK, Nicholls RD, Wu BL, Korf B, Knoll JHM. Allele specific replication of 15q11-q13 loci: a diagnostic test for uniparental disomy. Am J Hum Genet 1996;59:423-430.

12. Chess A, Simon I, Cedar H, Axel R. Allelic inactivation regulates olfactory receptor gene expression. Cell 1994;78:823-834.

13. Chess A. Expansion of the allelic exclusion principle? Science 1998;279:2067-2068.

14. Mostoslavsky R, Singh N, Tenzen T, Goldmit M, Gabay C, Elizur S, Qi P, Reubinoff BE, Chess A, Cedar H, Bergman Y. Asynchronous replication and allelic exclusion in the immune system. Nature 2001;414:221-225.

15. Amiel A, Avivi L, Gaber E, Fejgin MD. Asynchronous replication of allelic loci in Down syndrome. Eur J Hum Genet 1998;6:359-364.

16. Amiel A, Korenstein A, Gaber E, Avivi L. Asynchronous replication of alleles in genomes carrying an extra autosome. Eur J Hum Genet 1999;7:223-230.

17. Magenis RE, Berg WR, Clark KA, Hook EB, Palmer CG, Pasztor LM. Summitt RL, Vandyke D. Distribution of sex chromosome complements in 651 patients with Turner's syndrome. Am J Hum Genet 1980;32:79A.

18. Jacobs PA, Betts PR, Cockwell AE, Crolla JA, Mackenzie MJ, Robinson DO, Youings SA. A cytogenetic and molecular reappraisal of a series of patients with Turner's syndrome. Ann Hum Genet 1990;54:209-223.

19. Carrel L, Cottle AA, Goglin KC, Willard HF. A first-generation X-inactivation profile of the human X chromosome. Proc Natl Acad Sci U S A 1999;96:14440-14444.

20. Donnelly SL, Wolpert CM, Menold MM, Bass MP, Gilbert JR, Cuccaro ML, Delong GR, Pericak-Vance MA. Female with autistic disorder and monosomy X (Turner syndrome): parent-of-origin effect of the X chromosome. Am J Med Genet 2000;96:312-316.

21. Amiel A, Litmanovich T, Gaber E, Lishner M, Avivi L, Fejgin M. Asynchronous replication of p53 and 21q22 loci in chronic lymphocytic leukemia. Hum Genet 1997;101:219-222.

22. Amiel A, Litmanovitch T, Lishner M, Mor A, Gaber E, Tangi I, Fejgin MD, Avivi L. Temporal differences in replication timing of homologous loci in malignant cells derived from CML and lymphoma patients. Genes Chromosomes Cancer 1998;22:225-231.

23. Dotan ZA, Dotan A, Litmanovitch T, Ravia Y, Oniashvili N, Leibovitch I, Ramon J, Avivi L. Modification in the inherent mode of allelic replication in lymphocytes of patients suffering from renal cell carcinoma: a novel genetic alteration associated with malignancy. Genes Chromosomes Cancer 2000;27:270-273.

24. Amiel A, Kolodizner T, Fishman A, Gaber E, Klein Z, Beyth Y, Fejgin MD. Replication pattern of the 553 and $21 \mathrm{q} 22$ loci in the premalignant and malignant stages of carcinoma of the cervix. Cancer 1998;83:1966-1971.

25. Amiel A, Elis A, Sherker S, Gaber E, Manor Y, Fejgin MD. The influence of cytogenetic aberrations on gene replication in chronic lymphocytic leukemia patients. Cancer Genet Cytogenet 2001;125:81-86.

26. Litmanovitch T, Altaras MM, Dotan A, Avivi L. Asynchronous replication of homologous $\alpha$-satellite DNA loci in man is associated with non-disjunction. Cytogenet Cell Genet 1998;81:26-35.

27. Hasle H, Olsen JH, Nielsen J, Hansen J, Friedrich U, Tommerup N. Occurrence of cancer in women with Turner syndrome. Br J Cancer 1996;73:1156-1159.

28. Gravholt CH, Juul S, Naeraa RW, Hansen J. Morbidity in Turner syndrome. J Clin Epidemiol 1998;51:147-158.

29. Blatt J, Olshan AF, Lee PA, Ross JL. Neuroblastoma and related tumors in Turner's syndrome. J Pediatr 1997;131:666-670. 